\title{
A Comparative Study on the Female Domestic Workers and Their Children in Kamrup Districts of Assam
}

\author{
Ms. Bijoyeta Das ${ }^{1 *}$
}

\section{ABSTRACT}

This paper has been prepared to visualize relationships between the overall condition of the workers in Kamrup Metro and Kamrup rural areas of Assam. It throws light on how the female domestic workers engaged in part time work function differently in both the areas. The increase in the number of domestic workers has led to the growth of the urban middle class, especially the increase in the number of women working outside their homes and availability of cheap domestic labour. Kamrup Districts has witnessed large scale migration over the past few years of women from the interior areas of Assam, while in Kamrup metro, most of the migrants are from areas in lower Assam .The poor women who engage in domestic work are often unable to care for their own families, leaving their own children alone for the whole day. The study was conducted on adults ranging from 27 to 40 yrs of age. There were various reasons for which these female workers engaged in such kind of work, v.i.z, illiteracy, uncertain income of other family members and preference for part time domestic work, higher number of children with low income in the family. The children of such workers are sent to schools in Kamrup metro, while a handful of children were provided with education via various means in Kamrup rural. The wages of the workers in rural areas were not sufficient to send their children to proper schools. In this paper, some implications are provided to assist such workers in helping their children for education. The paper also deals with the educational status and the challenges faced by such workers in the daily affairs.

Keywords: Female Domestic Workers, Children, Kamrup District, Assam

A domestic worker is a person who works within the employer's household. The older English word for 'domestic worker' was 'servant', though not all servants worked inside home. Domestic service or the employment of people for wages in their employer's residence was sometimes called as 'service' and often been part of a hierarchical system. Domestic workers perform a variety of household services for an individual or a family, from providing care for children and elderly dependents to housekeeping, including washing utensils, cleaning and household

\footnotetext{
${ }^{1}$ Ph.D Research Scholar, Psychology Department, Gauhati University, Assam, India

*Responding Author

(c) 2016 I B Das; licensee IJIP. This is an Open Access Research distributed under the terms of the Creative Commons Attribution License (http://creativecommons.org/licenses/by/2.0), which permits unrestricted use, distribution, and reproduction in any Medium, provided the original work is properly cited.
} 


\section{A Comparative Study on the Female Domestic Workers and Their Children in Kamrup Districts of Assam}

maintenance. Other responsibilities may include cooking, laundry and ironing, shopping for food and undertaking other household errands.

Most of the domestic workers are from the marginalized sections of society and a large number of people are migrant workers. Workers range from full time to part time workers, skilled and unskilled workers. The Draft National Policy on Domestic Workers define domestic worker as a person who is employed for remuneration whether in cash or kind, in any household through any agency or directly, either on a temporary or permanent ,part time or full time basis to do the household work, but does not include any member of the family of an employer.

Both in the urban and rural contexts, the nature of work and workers have been rapidly changing. Domestic work, however, is still undervalued. It is looked upon as unskilled because most women have traditionally been considered capable of doing the work, and the skills they are taught by other women in the home are perceived to be innate. When paid, therefore, the work remains undervalued and poorly regulated. By contrast, studies that provide space for domestic workers to speak often reveal their belief in the dignity of their hard work, and, as such, it warrants recognition and respect and calls for regulation (D. Roberts 1997).

However, since the work is actually not monetised, people in general don't normatively accord 'domestic work' the values imputed in such studies. Instead, they devalue this work and many people consider it to be women's work. In India, across a variety of regional and cultural divisions, domestic work and childcare are widely considered to be women's work. It is often implicitly seen as undignified for a man to actually get involved in the dirty work of child cleaning, the messy work of dishwashing, or the time consuming women's jobs of cooking curries or sweeping the floors. In the 'global economy' there has been an emergence of a new professional class of workers that include well educated women. With this there has been a need for domestic servants to help the professionals in their daily chores (Padma 2002).

In India the National Sample Survey Organisation (NSSO) has repeatedly given measures of women's time spent on a variety of activities which broadly one can call the informal sector. These measures are, however, provided if and only if the woman first declares that she has no paid work, is not unemployed per se, and is doing domestic work only. She cannot declare herself self-employed either (although many Indian women do) so the category of 'housewives' is an appropriate label for this residual group of non-employed women who were asked the questions about unremunerated work. Most of them live in slums; lead a monotonous life without any colour, struggle everyday for their survival and face numerous problems in day today life like long hours of work, insecurity of job, low status at home and outside (Gathia 1983). Women in our society have so far had only a secondary status and the economic dependence of women upon men is one of the primary reasons which has pushed them into the background and resulted into their secondary status both within and outside the family (Wadhera 1976). In spite 


\section{A Comparative Study on the Female Domestic Workers and Their Children in Kamrup Districts of Assam}

of the fact that the women have proved their mettle in every walk of life, their contribution is not given due credit in most cases. In India women constitute nearly half of the total population and they play a vital role in domestic sphere, in the rural field and also in urban economy. Yet, their economic status is still low as it reflects from the census data, particularly of those who are engaged in the informal sector of urban economy (Tripathy and Das 1991).

The World Bank in its Annual Report in 1989 observed that 35 per cent of Indian households below the poverty line are headed by women, and in most cases, are thus, dependent exclusively on female income (Soni 2001). The increase in the number of domestic workers has led to the growth of the urban middle class, especially the increase in the number of women working outside their homes and availability of cheap domestic labour. There is a difference in the time schedule provided to the female domestic workers in urban and rural areas. The children of most of the workers shows a wide gap in education in comparison to the other section of society due to financial crisis. Another factor which is becoming an issue in some of the urban areas is of providing social security to such workers in work area.

This study throws light on the differences of the condition of such workers in the urban and rural areas of Kamrup Districts of Assam along with a difference in the children of such workers. There seems to be a tendency or opportunity for better education among the children in Kamrup metro in comparison to the ones in Kamrup rural. Hence the condition of such workers differs in various respects.

\section{REVIEW OF RELATED LITERATURE}

Kundu, A. In a study mentions that, the Government of India plans to implement a few regulations to facilitate better working and living conditions of the unorganised workers in both the urban and rural areas and that they should be included in the domain of unorganised workers. Such workers face various problems at the work place, which include over work load, low wage, minimal pay or no pay for extra work, absence of leave facility, no rest, sexual harassment by male employers etc (Madhumathi,M 2013). The working conditions of domestic workers are deplorable with long working hours and absence of job security.

Mehrotra, Surabhi(2010) views that the women are placed very low in social structure because of the little value ascribed to domestic work in our society. The academic achievement of the children of such workers especially females shows higher zeal towards proper education and being independent (Dehmler,2004).Some of the children of such workers had reported of substance abuse as a result of lack of education.

Most of the female domestic workers are found to be migrants, as a result of which they face difficulties in adjusting or adapting towards the life style, attitudes, habits and languages encountered in new living and work situations(Sabban,R 2012). 


\section{A Comparative Study on the Female Domestic Workers and Their Children in Kamrup Districts of Assam}

\section{OBJECTIVES}

The objectives of the study were as follows-

- To find out the differences in the working hours of the female domestic workers in Kamrup metro and Kamrup rural areas;

- To assess the adjustment level of the workers in various fields;

- To find out the differences in the educational status of the children of such workers in both the areas;

- To find out preventive measures for the overall development of the workers in both Kamrup metro and Kamrup rural areas.

\section{METHODOLOGY}

The sample consisted of 30 part time female domestic workers (15 from Kamrup metro and 15 from Kamrup rural).The age of the participants ranged from 27 to 40 years. An unstructured interview was used for the purpose. At the same time, an adjustment inventory was also used to find out the adjustment level of the workers in different areas. The cumulative academic score of the children of the workers were taken into account to find out the educational status of the children.

\section{Description of the tools-}

(i) Self Devised questionnaire-The self devised questionnaire was used to find out the condition and the reasons of such workers indulged in such work, their educational status etc.

(ii) Bell Adjustment Inventory-This inventory was developed by H.M Bell. It was used to assess the adjustment level of the workers in various fields.

(iii) Cumulative Academic Score-The Cumulative Academic Score of the children of such workers were taken into account to find out their educational status.

\section{PROCEDURE}

Before conducting the study, consent of the study was taken from the workers in both the areas. The sample was chosen to fulfil the purpose of the study. Researcher then visited the homes of the workers and filled up the questionnaires with the responses provided the participants. They were not forced to give any responses. The academic performance of the children was taken into account by noting down the cumulative academic score of them. The reports were kept as confidential. Lastly, the workers and their children were thanked for their co-operation.

\section{RESULTS AND DISCUSSION}

After collecting data, further analysis of data was done to find out the differences of the scores of Kamrup metro and Kamrup rural areas. Some of the reasons for which they engaged in such work are as follows-illiteracy, uncertain income of the other family members and preference for various part time domestic workers, higher number of children with low income in the family. 
In Kamrup metro, it was seen that most of the workers were migrants from lower areas of Assam. The children of such workers especially the female children had reported of going to schools. The female workers even viewed that education is of higher importance for the upcoming generation to fight against the odds of their life. Most of them reported of their husbands working as rickshaw pullers, carpenters while some were unemployed etc. The wages of such workers were found to be sufficient enough to fulfil their basic needs and to send their children to govt. schools and colleges. Some of the college going children of such workers was found to work in certain NGOs in order to help their family.

While in Kamrup rural, it was found that the female child remained unprivileged towards educational facilities. The wages of the parents were not enough to send both the children to school. A handful amount of children showed good academic score. Illiteracy tends to be one of the causes amongst the parents for which the awareness of education was lacking behind and keeping the child away from school. The workers reported of male children being a part of substance abuse at times.

The statistical analysis of the scores of the female domestic workers and the academic score of the children was done.

(i) Mean (M) was used to find out the average score of the sample.

(ii) Standard Deviation (SD) was used to measure the co-efficient of correlation and other statistics.

(iii) t-test was used to compare the adjustment level of the female domestic workers in Kamrup metro and Kamrup rural areas.

Table 1.1: Table showing the classification scores of $t$ test of the adjustment level of the Female domestic workers of Kamrup Metro and Kamrup Rural-

\begin{tabular}{|l|c|l|l|l|l|l|}
\hline & N & MEAN & SD & t & df & $\begin{array}{l}\text { Significance(2 } \\
\text { tailed) }\end{array}$ \\
\hline $\begin{array}{l}\text { Kamrup } \\
\text { Metro }\end{array}$ & 15 & 24.06 & 6.89 & 2.105 & 28 & .044 \\
\cline { 1 - 1 } $\begin{array}{l}\text { Kamrup } \\
\text { Rural }\end{array}$ & 15 & 29.40 & 6.98 & & & \\
\hline
\end{tabular}

This table indicates that the workers in Kamrup rural are found to be well adjusted in all areas in comparison to the workers in Kamrup metro. In Kamrup metro, most of the workers showed low scores in social and emotional adjustment. Most of the female domestic workers were migrants from different areas in Kamrup metro and they had to adapt to various ways of living, language etc. 
Table 1.2: Table showing the classification scores of $t$ test of the academic scores of the children of the female domestic workers of Kamrup Metro and Kamrup Rural-

\begin{tabular}{|c|c|c|c|c|c|c|}
\hline & $\mathbf{N}$ & MEAN & SD & $\mathbf{t}$ & df & $\begin{array}{l}\text { Significance } \\
\text { (2 tailed) }\end{array}$ \\
\hline $\begin{array}{l}\text { Kamrup } \\
\text { Metro }\end{array}$ & 15 & 8.53 & 0.99 & \multirow[t]{2}{*}{0.554} & \multirow[t]{2}{*}{28} & \multirow[t]{2}{*}{.584} \\
\hline Kamrup Rural & 15 & 8.26 & 1.57 & & & \\
\hline
\end{tabular}

The above table indicates that the children of the workers in Kamrup metro reported of higher academic score in comparison to the children in Kamrup rural areas. Some of the reasons contributing to this factor were-lack of awareness or illiteracy amongst the parents of such children, insufficient income for sending the children to proper schools, lack of facilities provided by the govt. in such areas.

Table 1.3: Table indicating the average monthly wages of the female domestic workers-

\begin{tabular}{|l|c|l|c|}
\hline \multicolumn{2}{|c|}{ KAMRUP METRO } & \multicolumn{2}{c|}{ KAMRUP RURAL } \\
\hline \multicolumn{1}{|c|}{ WAGES } & NO. OF WORKERS & \multicolumn{1}{c|}{ WAGES } & NO. OF WORKERS \\
\hline Less than 500 & 0 & Less than 500 & 04 \\
\hline $500-1000$ & 05 & $500-1000$ & 09 \\
\hline $1000-1500$ & 07 & $1000-1500$ & 02 \\
\hline More than 1500 & 03 & More than 1500 & 0 \\
\hline
\end{tabular}

The wages of the female domestic workers is found to be higher in Kamrup Metro in comparison to the ones in Kamrup Rural.

Table 1.4: Table depicting the hours worked by Female domestic workers in Kamrup Rural and Kamrup Metro-

\begin{tabular}{|l|l|l|c|}
\hline \multicolumn{2}{|l|}{ KAMRUP METRO } & \multicolumn{1}{c|}{ KAMRUP RURAL } \\
\hline $\begin{array}{l}\text { NO. AND } \\
\text { DESCRIPTION OF } \\
\text { HOURS OF THE } \\
\text { WORKERS }\end{array}$ & $\begin{array}{l}\text { NO. OF } \\
\text { WORKERS }\end{array}$ & $\begin{array}{l}\text { NO.AND DESCRIPTION } \\
\text { OF HOURS OF THE } \\
\text { WORKERS }\end{array}$ & $\begin{array}{l}\text { NO. OF } \\
\text { WORKERS }\end{array}$ \\
\hline 8 hours and above & 03 & 8 hours and above & Nil \\
\hline 5-7 hours & 02 & 5-7 hours & 07 \\
\hline 3-4 hours & 01 & 3-4 hours & 05 \\
\hline 1-2 hours & 08 & 1-2 hours & 03 \\
\hline
\end{tabular}




\section{A Comparative Study on the Female Domestic Workers and Their Children in Kamrup Districts of Assam}

The workers who were indulged as baby sitter or other miscellaneous domestic chores had spent 8 hours and above in their workplace. While in Kamrup rural areas, there were no reports of the workers indulging as baby sitters or such miscellaneous work.

\section{CONCLUSION}

It can be concluded that the scenario of the female domestic workers in Kamrup rural was found to be comparatively better in comparison to Kamrup metro in relation to adjustment. Whereas, the children of such workers in Kamrup were somehow benefitted by the prevailing developed educational facilities in the area as compared to the ones in the rural areas. The workers had faced various problems in both the areas, v.i.z. poor housing conditions, exposure to excessive heat, cold, diseases and lack of proper hygiene etc. The Govt. of Assam should implement some regulations to facilitate the better working and living conditions of the female domestic workers in the Kamrup Districts. Importance must be given to some factors v.i.z. overtime pay, public holidays, timely payment of salaries, standard daily working hours, ensuring safety regulations and provision of paid leave.

\section{REFERENCES}

Gulati, J. k and Datta, Jayanti (2004).Mental Health profit of rural adolescents living in persistent economic hardship, Man in India,84(1 and 2)

Kundu,A(2007).Condition of Work and Rights of Female Domestic Workers of Kolkata. SEWAISST, 2008; Socio-Economic Condition of Domestic Workers in Ahmedabad.FES, New Delhi.

Madhumathi, M.(2010).“Urban Poverty and Domestic Workers”.

Madhumathi, M.(2013). "Migration for Domestic Work-A Case of Female Domestic Workers in Bangalore”.

Mehrotra, Surabhi.(2010).Domestic Workers: A Study of Part time domestic Workers in Delhi. Mehta.A (1960). "The Domestic Servant Class".

Neethe,N.2003.Migration,Social Networking and Employment: A study of Domestic Workers in Delhi,NLI Research Studies, No. 37,V.V Giri National Labour Institute, Noida.

O. Sarkar, Siddhartha(2005) "Women as Paid Domestic Workers" Social Science Journal, Vol And No.11(1)p.35-41.

Sabban, R (2012):Migrant Women in the UAE. The Case of Female Domestic Workers. 